\title{
Analysis of Sphenoid Sinus and Surrounding Structures Using Multidetector Computed Tomography
}

\author{
Jae Min Shin, Won Ik Jang and Byoung Joon Baek \\ Department of Otolaryngology-Head and Neck Surgery, Soonchunhyang University College of Medicine, Cheonan Hospital, \\ Cheonan, Korea
}

\section{다중검출 전산화단층촬영을 이용한 접형동과 주위 구조물 분석}

신재민 · 장원익 · 백병준

순천향대학교 의과대학 천안병원 이비인후과학교실

Received December 27, 2011

Revised January 27, 2012

Accepted January 28, 2012

Address for correspondence

Byoung Joon Baek, MD, PhD

Department of Otolaryngology-

Head and Neck Surgery,

Soonchunhyang University

College of Medicine,

Cheonan Hospital,

31 Suncheonhyang 6-gil,

Dongnam-gu, Cheonan 330-721,

Korea

Tel $+82-41-570-2265$

Fax $+82-41-579-9022$

E-mail bjbaek@schmc.ac.kr
Background and Objectives Sphenoid sinus is surrounded by several important structures and this can make sphenoid sinus surgeries difficult. The aim of this study was to clarify the anatomical features of the sphenoid sinus with its surrounding structures based on 3-dimensional multidetector computed tomography.

Subjects and Method We obtained the sagittal reconstruction images of the sphenoid sinus from of 110 participants and measured various distances in the sphenoid sinus. In addition, we analyzed the impact of anatomical variation on the results of measured distances, such as presence of Onodi cell (Onodi type vs. non-Onodi type) and the location of sphenoid ostium corresponding to the level of sella floor (superior type vs. inferior type).

Results In the Onodi type, the mean distance from the sphenoid ostium to the roof of sphenoid sinus $(5.81 \pm 1.12 \mathrm{~mm}$ vs. $10.31 \pm 2.90 \mathrm{~mm}, p=0.001)$ and the mean length of sphenoid sinus roof $(4.52 \pm 1.00 \mathrm{~mm}$ vs. $9.89 \pm 4.17 \mathrm{~mm}, p=0.001)$ were significantly shorter than those in the non-Onodi type. In superior type, the mean distance from the sphenoid ostium to the floor of sphenoid sinus $(12.44 \pm 2.63 \mathrm{~mm}$ vs. $9.90 \pm 2.31 \mathrm{~mm}, p<0.001)$ and that from sphenoid ostium to the posterior wall of sphenoid sinus $(13.44 \pm 3.27 \mathrm{~mm}$ vs. $20.38 \pm 7.63 \mathrm{~mm}, p<0.001)$ were significantly longer compared with those in the inferior type. However, the mean distance from the sphenoid ostium to the roof of sphenoid sinus was shorter $(7.49 \pm 1.86 \mathrm{~mm}$ vs. $10.51 \pm 3.03$ $\mathrm{mm}, p<0.001$ ).

Conclusion The present study provides anatomical information about sphenoid sinus with important surgical distance measured between the sphenoid ostium and the surrounding structures, which is essential to avoid the complications during sphenoid surgery.

Korean J Otorhinolaryngol-Head Neck Surg 2012;55:95-100

Key Words Sphenoid sinus - Anatomic landmarks $\cdot$ Radioanatomic analysis $\cdot$ Multidetector computed tomography.

\author{
서 론 \\ 부비동 질환의 수술적 치료로서 비내시경을 사용하는 것이 \\ 보편화되었고, 뇌하수체 선종 제거와 같은 두개저 수술시에도 \\ 비내시경을 이용한 경접형동 접근법(transsphenoidal appro- \\ $\mathrm{ach}$ )이 널리 이루어지고 있다. 접형동은 시신경 및 내경동맥, 두
}

개저, 뇌하수체와 같은 중요 구조물들과 인접해 있으며 해부학 적 변이가 다양하여 수술적 접근이나 처치시 주위 구조물의 손상 가능성이 항상 존재하기 때문에 ${ }^{1)}$ 접형동 수술시 발생 가 능한 합병증을 최소화하기 위하여 수술 전 해부학적 구조를 미리 숙지하는 것이 중요하다.

현재까지 computed tomography(CT) 영상이나 사체 해부 
를 통해 접형동과 주의 구조물의 상관관계를 분석한 연구들 ${ }^{2-5)}$ 이 다수 발표되었지만, 사체 해부를 통한 접형동을 계측한 연 구의 경우 사체 처리 과정에서 포르말린에 의한 변형으로 오류 가 발생할 수 있으며, ${ }^{6} \mathrm{CT}$ 영상을 이용하여 분석한 연구에서도 해부학적 변이의 정도 및 빈도 위주로 연구되어, ${ }^{7,8)}$ 수술시 활 용할 수 있는 유용한 정보를 제공하지 못했던 것이 사실이다.

최근 기술의 발달로 3차원 다중검출 전산화단층촬영(3- dimensional multidetector computed tomography, 3D MD$\mathrm{CT}$ )을 통하여 축면(axial) 영상을 촬영한 뒤 관상면 영상(coronal)과 시상면(sagittal) 영상을 3차원적으로 재구성하는 기술 이 개발됨에 따라, 과거 축면 및 관상면 영상만으로는 측정이 어려웠던 접형동과 주요 구조물들 간의 거리 및 주요 구조물 들의 변이를 입체적으로 파악하는 것이 가능해졌다. ${ }^{8-10)}$

이에 저자들은 $3 \mathrm{D} \mathrm{MDCT}$ 를 기반으로 접형동 수술에서 해 부학적 기준점이 되는 자연공을 기준으로 접형동의 상벽, 하벽, 후벽 및 터키안까지의 해부학적 거리를 Line 1 6로 설정하여 측정 및 분석하였고, Onodi cell 및 터키안 위치 등 해부학적 변이에 따른 거리의 변화를 비교 분석하였다. 이를 바탕으로 접형동 자연공을 기준으로 측정된 수술 전 정보를 파악하여, 수술 중 발생할 수 있는 합병증을 예방하는 데 도움을 주고자 하였다.

\section{대상 및 방법}

\section{대 상}

2009년 1월부터 2010년 12월까지 본원에서 부비동 내시경 수 술을 시행받은 환자들 중 술 전에 3D MDCT를 시행한 환자 의 의무기록을 후향적으로 분석하였다. 분석 대상은 접형동 내 부에 병변이 없으면서 접형동의 자연공을 확인할 수 있었던 110 명, 220예의 접형동을 대상으로 하였으며 분석 대상 중 남자 61명(55.5\%), 여자 49명(44.5\%)이었으며, 평균연령은 42세(16 78세)였다. 과거 부비동 수술을 받은 적이 있거나, 비부비강 및 뇌하수체 종양으로 진단 받은 경우, 비부비강 및 안면의 선천 적 기형이 있는 경우는 분석에서 제외하였다. 그리고 Hammer와 $\operatorname{Redberg}^{11)}$ 의 분류를 기준으로 접형동의 함기화가 거의 진행되 지 않은 갑개형(conchal type)의 경우도 분석에서 제외하였다.

\section{방 법}

전산화단층촬영은 Light speed VCT 64 scanner(General Electric medical systems, Milwaukee, WI, USA)를 사용하여 0.969 pitch, $120 \mathrm{kV}(\mathrm{p}), 330 \mathrm{mAs}$ 의 조건으로 orbitomeatal line에 평행하게 전두동 상연으로부터 경구개 상연까지 0.625 $\mathrm{mm}$ 절편 두께(slice thickness)로 축면 영상을 촬영하였고, 3
차원적 재구성은 Advantage workstation version 4.3(General Electric medical systems, Milwaukee, WI, USA)을 이용하 여 $1.25 \mathrm{~mm}$ 절편두께의 관상면과 시상면 영상을 얻었다.

영상학적 계측은 $\mathrm{Wu}$ 등히이 정의한 지표를 참고로 접형동 자연공의 중심에서 접형동 상벽의 길이를 Line 1 , 접형동 하벽 의 길이를 Line 2 로 설정하였고, 접형동 자연공의 중심에서 두 개저와 평행하게 연장하였을 때 접형동 후벽까지의 길이를 Line 3, 접형동 전벽에서 터키안(sella)까지의 길이를 Line 4, 접형동 천정(roof)의 길이를 Line 5, 접형동의 전후 최장길이를 Line 6으로 설정하여 측정 및 분석하였다(Fig. 1).

$3 \mathrm{D} \mathrm{MDCT}$ 영상에서 후사골동의 후벽이 접형동의 전벽을 지나 외측 및 상방으로 확대되는 경우 Onodi cell로 정의하였 으며, Onodi cell의 존재 여부에 따라 Onodi type과 non-Onodi type으로 분류하여, Onodi cell 유무에 따른 영상학적 계측 치의 변화를 분석하였다(Fig. 2).

그리고 접형동 자연공과 터키안 최저점과의 위치를 기준으 로, 접형동 자연공이 터키안 최저점보다 위쪽에 있는 경우를 superior type, 아래쪽에 위치하는 경우를 inferior type으로 정 의하였고, $3 \mathrm{D} \mathrm{MDCT}$ 영상을 분석하여 각 type의 관찰 빈도 및 type의 차이에 따른 영상학적 계측치의 차이를 비교 분석하였 다(Fig. 3).

계측한 자료는 SPSS program version 18(SPSS Inc., Chicago, IL, USA)을 이용하여 분석하였고, 각 군 간의 계측치의 차이는 independent t-test를 사용하여 통계학적 유의성을 검

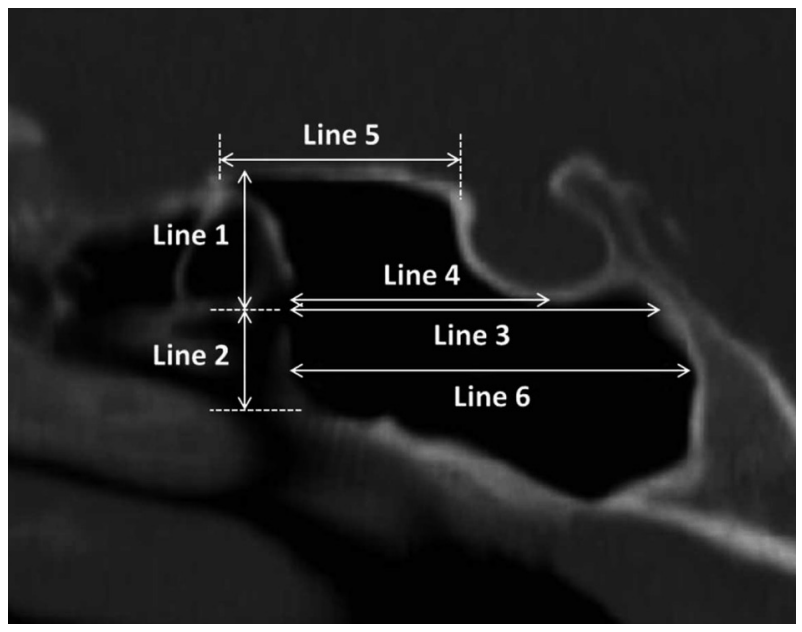

Fig. 1. Measurements of the sphenoid sinus lengths at the level of sphenoid ostium in sagittal plane. Line 1: the vertical distance from the center of the sphenoid ostium to the roof of the sphenoid sinus, Line 2: the vertical distance from the center of the sphenoid ostium to the floor of the sphenoid sinus, Line 3: the horizontal distance from the center of the sphenoid ostium to the posterior wall of the sphenoid sinus, Line 4: the horizontal distance from the anterior wall of the sphenoid sinus to the lowest point of the sella, Line 5: the length of the sphenoid sinus roof, Line 6: the longest horizontal distance of the sphenoid sinus. 

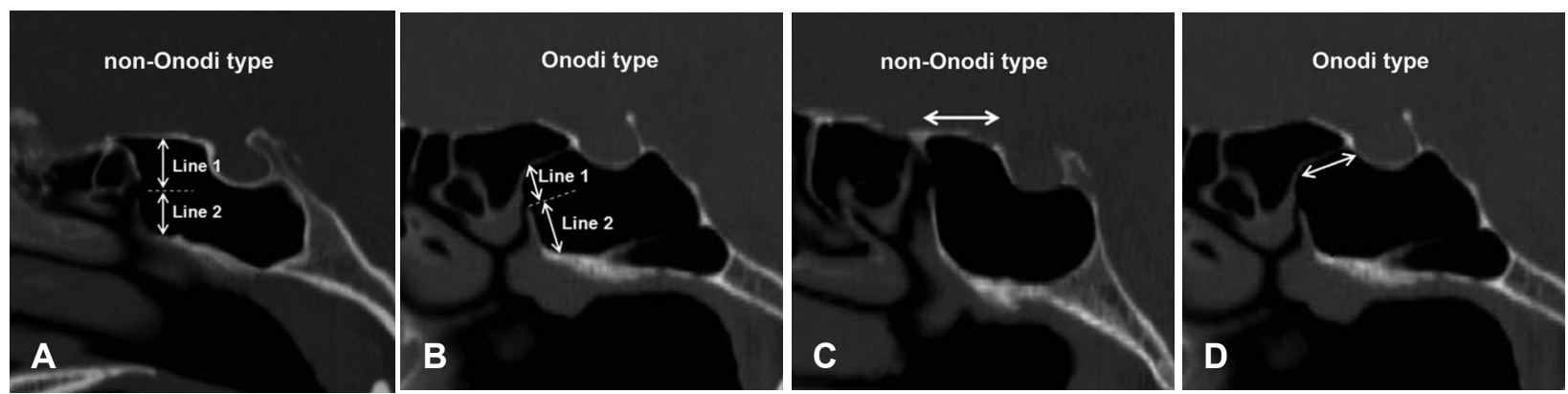

Fig. 2. Measurements of Line 1 and Line 2 in non-Onodi type (A). Measurements of Line 1 and Line 2 in Onodi type (B). Measurement of Line 5 in non-Onodi type (C). Measurement of Line 5 in Onodi type (D). Line 1: the vertical distance from the center of the sphenoid ostium to the roof of the sphenoid sinus, Line 2: the vertical distance from the center of the sphenoid ostium to the floor of the sphenoid sinus, Line 5: the length of the sphenoid sinus roof.

Fig. 3. Measurement of Line 3 in superior type (A). Measurement of Line 3 in inferior type (B). Line 3: the horizontal distance from the center of the sphenoid ostium to the posterior wall of the sphenoid sinus.
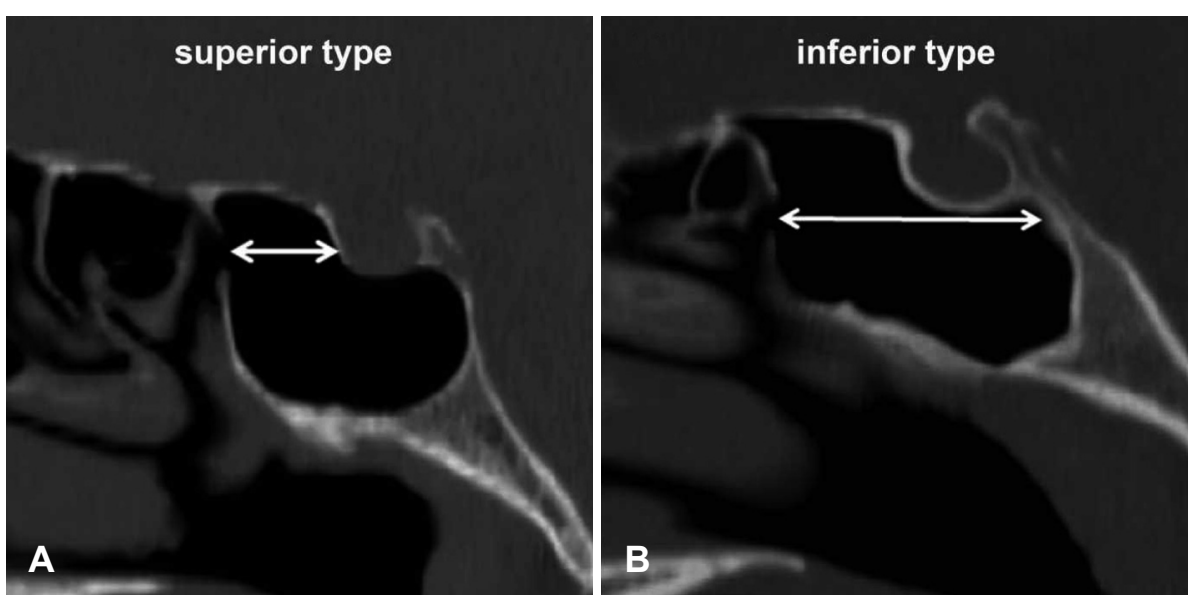

Table 1. Measurements of the sphenoid sinus lengths (mean \pm SD)

\begin{tabular}{ccccc}
\hline & Right side $(\mathrm{mm})$ & Left side $(\mathrm{mm})$ & Total $(\mathrm{mm})$ & p-value \\
\hline Line 1 & $10.03 \pm 3.28$ & $9.91 \pm 2.88$ & $9.97 \pm 3.06$ & 0.321 \\
Line 2 & $10.22 \pm 2.43$ & $10.65 \pm 2.74$ & $10.44 \pm 2.60$ & 0.525 \\
Line 3 & $18.86 \pm 7.22$ & $18.94 \pm 7.78$ & $18.90 \pm 7.48$ & 0.872 \\
Line 4 & $13.52 \pm 4.04$ & $13.08 \pm 3.86$ & $13.29 \pm 3.94$ & 0.500 \\
Line 5 & $9.59 \pm 4.37$ & $9.34 \pm 4.21$ & $9.46 \pm 4.28$ & 0.501 \\
Line 6 & $25.32 \pm 7.75$ & $25.86 \pm 7.37$ & $25.59 \pm 7.55$ & 0.708 \\
\hline
\end{tabular}

Line 1: the vertical distance from the center of the sphenoid ostium to the roof of the sphenoid sinus, Line 2: the vertical distance from the center of the sphenoid ostium to the floor of the sphenoid sinus, Line 3: the horizontal distance from the center of the sphenoid ostium to the posterior wall of the sphenoid sinus, Line 4: the horizontal distance from the anterior wall of the sphenoid sinus to the lowest point of the sella, Line 5: the length of the sphenoid sinus roof, Line 6: the longest horizontal distance of the sphenoid sinus. SD: standard deviation

증하였으며, 통계학적 유의성은 $p<0.05$ 로 정의하였다.

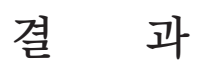

접형동 내부의 주요 계측치 평균값 중 접형동 자연공에서 접 형동 천정까지의 거리를 의미하는 Line 1은 평균 $9.97 \pm 3.06$ $\mathrm{mm}$ 로 측정되었고, 접형동 자연공에서 접형동 바닥까지의 거 리를 의미하는 Line 2 는 평균 $10.44 \pm 2.60 \mathrm{~mm}$ 로 측정되었다. 접형동 자연공에서 orbitomeatal line과 평행하게 연장하였을 때 접형동 후벽까지의 거리를 의미하는 Line 3는 평균 $10.90 \pm$
$7.48 \mathrm{~mm}$, 접형동 전벽에서 터키안까지의 거리를 의미하는 Line 4는 평균 $13.29 \pm 3.94 \mathrm{~mm}$ 로 측정되었다. 그리고 접형동 천정의 길이(Line 5)는 평균 $9.46 \pm 4.28 \mathrm{~mm}$ 로 측정되었으며, 접형동 전후 최장길이(Line 6)의 평균은 $25.59 \pm 7.55 \mathrm{~mm}$ 로 측정되었 다. 접형동을 좌우측으로 구분하여 측정 및 분석한 결과에서 도 전체 평균치와 유사한 결과가 관찰되었고, 좌우측 계측치 평균값 사이에 유의한 차이는 없었다(Table 1).

Onodi cell은 전체 220예 중에 28예(12.7\%)에서 존재하였으 며, Onodi cell의 존재 여부에 따라 non-Onodi type과 Onodi type으로 구분하여 접형동 내부의 계측치를 분석한 결과에서, 
Table 2. Measurements of the sphenoid sinus lengths between non-Onodi type and Onodi type (mean \pm SD)

\begin{tabular}{lcrr}
\hline & Non-Onodi type $(\mathrm{n}=192)$ & Onodi type $(\mathrm{n}=28)$ & $\mathrm{p}$-value \\
\hline Line 1 & $10.31 \pm 2.90 \mathrm{~mm}$ & $5.81 \pm 1.12 \mathrm{~mm}$ & $<0.001$ \\
Line 2 & $10.57 \pm 2.61 \mathrm{~mm}$ & $9.23 \pm 2.10 \mathrm{~mm}$ & 0.688 \\
Line 3 & $19.46 \pm 7.39 \mathrm{~mm}$ & $13.79 \pm 6.53 \mathrm{~mm}$ & 0.240 \\
Line 4 & $13.77 \pm 3.74 \mathrm{~mm}$ & $8.92 \pm 3.09 \mathrm{~mm}$ & 0.140 \\
Line 5 & $9.89 \pm 4.17 \mathrm{~mm}$ & $4.52 \pm 1.00 \mathrm{~mm}$ & $<0.001$ \\
Line 6 & $26.05 \pm 7.30 \mathrm{~mm}$ & $21.41 \pm 8.56 \mathrm{~mm}$ & 0.115 \\
\hline
\end{tabular}

Line 1: the vertical distance from the center of the sphenoid ostium to the roof of the sphenoid sinus, Line 2: the vertical distance from the center of the sphenoid ostium to the floor of the sphenoid sinus, Line 3: the horizontal distance from the center of the sphenoid ostium to the posterior wall of the sphenoid sinus, Line 4: the horizontal distance from the anterior wall of the sphenoid sinus to the lowest point of the sella, Line 5: the length of the sphenoid sinus roof, Line 6: the longest horizontal distance of the sphenoid sinus. SD: standard deviation

Table 3. Measurements of the sphenoid sinus lengths between superior type and inferior type (mean $\pm \mathrm{SD}$ )

\begin{tabular}{lcrr}
\hline & Superior type $(\mathrm{n}=52)$ & Inferior type $(\mathrm{n}=168)$ & $\mathrm{p}$-value \\
\hline Line 1 & $7.49 \pm 1.86 \mathrm{~mm}$ & $10.51 \pm 3.03 \mathrm{~mm}$ & $<0.001$ \\
Line 2 & $12.44 \pm 2.63 \mathrm{~mm}$ & $9.90 \pm 2.31 \mathrm{~mm}$ & $<0.001$ \\
Line 3 & $13.44 \pm 3.27 \mathrm{~mm}$ & $20.38 \pm 7.63 \mathrm{~mm}$ & $<0.001$ \\
Line 4 & $14.92 \pm 3.26 \mathrm{~mm}$ & $12.85 \pm 4.01 \mathrm{~mm}$ & 0.106 \\
Line 5 & $10.20 \pm 3.77 \mathrm{~mm}$ & $9.13 \pm 4.40 \mathrm{~mm}$ & 0.158 \\
Line 6 & $27.30 \pm 5.72 \mathrm{~mm}$ & $25.14 \pm 7.91 \mathrm{~mm}$ & 0.164 \\
\hline
\end{tabular}

Line 1: the vertical distance from the center of the sphenoid ostium to the roof of the sphenoid sinus, Line 2: the vertical distance from the center of the sphenoid ostium to the floor of the sphenoid sinus, Line 3: the horizontal distance from the center of the sphenoid ostium to the posterior wall of the sphenoid sinus, Line 4: the horizontal distance from the anterior wal of the sphenoid sinus to the lowest point of the sella, Line 5: the length of the sphenoid sinus roof, Line 6: the longest horizontal distance of the sphenoid sinus. SD: standard deviation

Onodi type인 경우 non-Onodi type과 비교하여 전반적으로 모든 계측치의 평균값이 짧게 측정되었으나, Line 1(5.81⒈12 $\mathrm{mm}$ vs. $10.31 \pm 2.90 \mathrm{~mm}, p=0.001)$ 과 Line $5(4.52 \pm 1.00 \mathrm{~mm}$ vs. $9.89 \pm 4.17 \mathrm{~mm}, p=0.001)$ 에서만 통계적 유의성을 보였다 (Table 2).

접형동 자연공과 터키안 최저점의 위치에 따른 접형동 내부 의 주요 계측치의 변화를 비교 분석한 결과에서, 접형동 자연 공이 터키안 최저점보다 상부에 위치하는 superior type의 경 우는 200예 중에 52예(26\%)에서 관찰되었고, 접형동 자연동 이 터키안 최저점보다 하부에 위치하는 inferior type의 경우 는 168예(74\%)에서 관찰되었다(Table 3). 접형동 자연공의 위치 에 따른 계측치의 차이는 superior type이 inferior type과 비 교해서 Line 1 의 평균치가 유의하게 짧았으며 $(7.49 \pm 1.86 \mathrm{~mm}$ vs. $10.51 \pm 3.03 \mathrm{~mm}, p<0.001)$, Line $2(12.44 \pm 2.63 \mathrm{~mm}$ vs. 9.90 $\pm 2.31 \mathrm{~mm}, p<0.001)$ 와 Line $3(13.44 \pm 3.27 \mathrm{~mm}$ vs. $20.38 \pm$ $7.63 \mathrm{~mm}, p<0.001)$ 는 길게 관찰되었다. 그리고 나머지 Line 4
6은 각 type 간 약간의 차이는 있었지만 통계학적 유의성은 없 었다(Table 3).

\section{고 찰}

접형동은 개인에 따라 해부학적 변이가 심하고 인접 주요 구 조물과의 관계가 복잡하기 때문에 ${ }^{12)}$ 내시경 부비동 수술시 해 부학적 특징을 숙지하는 것은 수술자의 입장에서 대단히 중 요하다. 과거 접형동의 해부학적 구조를 이해하기 위한 많은 노 력들이 있었지만, 대부분 접형동 함기화의 정도 및 함기화에 의 한 내경동맥, 시각신경, 상악신경 및 익돌관신경(nerve of pterygoid canal) 등 주요 구조물의 융기 및 뼈결손의 빈도를 조사 하거나, 접형동 중격 및 부중격의 형태와 빈도, 내경동맥과 중 격의 부착형태 등 해부학적 변이의 발생빈도를 확인하는 형태 의 연구가 진행되었다. ${ }^{3)}$ 하지만 이런 연구 결과들은 수술을 계 획하는 단계에서는 유용한 정보를 제공하지만, 실제 수술시야 에서 적용하기에는 제한적인 정보를 제공하기 때문에 수술 중 가장 많이 사용되는 해부학적 지표를 기준으로 한 접형동 구조 에 대한 이해가 필요하다.

접형동 자연공은 경접형동 접근법이나 내시경을 이용한 접형 동 수술시 가장 기본이 되는 해부학적 기준점(anatomical landmark)으로 사용되며, ${ }^{13)}$ 접형동 자연공의 확인이 어려울 경우 접 형동 전벽을 추정하여 접형동 절개술을 시행하기도 하지만, ${ }^{14,15)}$ 접형동 자연공을 확인한 후 수술을 진행하는 방법 ${ }^{16-18)}$ 이 가장 확실하고 안전한 방법으로 알려졌다. 이런 이유로 접형동 자연 공을 기준으로 접형동 전벽의 길이, 접형동의 크기 및 접형동 주요 주위구조물까지의 거리에 대한 기준치가 있다면 수술 중 접형동 자연공의 확장 방향 및 범위를 결정할 수 있고 접형동 자연공을 통한 기구조작시 주위 구조물의 손상을 예방할 수 있을 것이다. 하지만 과거 일반적으로 사용되었던 CT 영상의 경 우 축면 또는 관상면 영상만을 제공하기 때문에 접형동의 자연 공을 비롯한 인접 구조물과의 관계를 파악하는 데에 한계가 있었다. ${ }^{19,20}$ 최근 영상기술의 발달로 저자들은 다중검출 전산 화단층촬영기를 이용하여 $0.625 \mathrm{~mm}$ 의 절편 두께로 축면 영상 을 촬영한 후 3차원적 재구성을 통하여 관상면, 시상면 영상을 관찰함으로써 기존의 연구보다 접형동의 자연공 및 주위 구조 물과의 관계를 더욱 정확하게 측정할 수 있었다.

본 연구에서는 접형동 수술에 도움이 될 수 있는 6개의 지표 (Line 1 6)를 접형동 자연공을 기준으로 설정하여 측정 평균치 를 제시하였다. 접형동 자연공에서 접형동 천정까지 접형동 전 벽의 거리(Line 1)는 $9.97 \pm 3.06 \mathrm{~mm}$ 로 접형동 자연공에서 접 형동 바닥까지의 접형동 전벽의 거리(Line 2)인 $10.44 \pm 2.60 \mathrm{~mm}$ 와 유사한 거리를 보였다. 이런 결과치는 접형동 자연공을 해부 
학적 기준점으로 하여 접형동 전벽을 확장하는 경우 통한 상 측 및 하측으로 $4 \mathrm{~mm}$ suction tip 직경을 기준으로 2.5 개 크기 까지 확장이 가능하다는 것을 의미한다. 하지만 접형동 자연공 과 후비공 상연의 중간부분에 접형구개 동맥(sphenopalatine artery)의 분지인 비중격 동맥(nasoseptal artery)이 주행하기 때문에 ${ }^{21}$ 접형동 전벽을 제거하여 확장하는 경우 하측으로 확 장하는 경우보다 상측으로 더 넓게 확장이 가능할 것으로 판 단된다.

Line 4는 접형동 전벽에서 터키안까지의 평균거리로 수술시 접형동 자연공을 통해 기구를 삽입하여 조작하는 경우 $13.29 \pm$ $3.94 \mathrm{~mm}$ 이상으로 넣을 경우 터키안 전벽에 손상을 가할 가능 성이 있음을 의미하고, 접형동 중격 및 부중격의 변이로 터키안 의 위치를 확인하기 어려운 경우 자연공으로부터 거리를 측정 하여 터키안의 위치를 찾는 데 도움이 될 것으로 생각된다.

과거 $\mathrm{Tan}$ 과 $\mathrm{Ong}^{2)}$ 의 연구에서 연구대상의 94\%(45/48)의 접 형동에서 좌우측 함기화의 차이가 발생하고, 함기화가 더 진행 된 우성(dominant) 접형동의 빈도가 우측(62\%)이 높은 것으 로 발표하였다. 하지만 본 연구의 평균 계측치는 좌우측 사이 에 차이가 없었는데, 이런 결과의 차이는 대상군 선별에서 접형 동 함기화가 진행되지 않은 conchal형을 제외하여 분석한 이 유도 있겠지만, 저자들이 설정한 계측치가 접형동의 함기화정 도에 큰 영향을 받지 않는 것으로 생각된다.

해부학적 변이에 따른 영향을 확인하기 위해 저자들은 접형 동 위쪽으로 함기화가 진행된 후사골봉소(posterior ethmoid cell)를 Onodi cell로 정의하였으며, Onodi cell의 출현 빈도 및 출현에 따른 설정한 계측치의 변화를 분석하였다. Onodi cell 의 출현빈도는 $12.7 \%$ 로 기존의 연구인 9 16\% $\%^{4,22,23}$ 와 유사하 게 관찰되었지만, $\mathrm{Yeoh}$ 와 $\operatorname{Tan}^{24}$ 이 보고한 $51 \%$ 와는 차이가 나 는데, 이는 Onodi cell의 정의 및 측정방법의 차이에 따른 결 과로 판단된다. Onodi cell이 존재하는 Onodi type의 경우 non-Onodi type과 비교하여 Line 2 를 제외한 모든 계측치의 값이 감소하였으며, 이는 Onodi cell이 발달할 경우 접형동의 함기화를 저해하여 접형동의 크기가 작아지는 결과를 초래하 는 것으로 생각된다. 특히 Line 1 과 Line 5의 평균 계측치가 의미 있게 짧아지는데, 이는 접형동 자연공에서 접형동 천정까 지의 거리 및 접형동 천정의 길이가 짧아짐을 뜻하며, 접형동 자연공을 통하여 접형동 전벽을 확장할 때 접형동 전벽을 상 측으로만 제거해서는 충분한 수술시야를 확보하기 어려울 뿐 아니라 접형동 전벽에서 터키안까지의 거리가 짧아져 수술시 터키안 손상의 위험성이 증가할 것으로 생각된다. 반면 Line 2 계측치의 변화는 큰 차이가 없어 Onodi type인 경우 접형동 자연공을 기준으로 접형동 하측 전벽을 충분히 확장하여 수술 시야를 확보하는 것이 필요할 것으로 생각된다.
그리고 본 연구에서는 접형동 자연공의 위치와 터키안 최저 점의 위치를 기준으로 superior type과 inferior type으로 구분 하여 분석하였는데, 접형동 자연공의 위치가 터키안 최저점보 다 높게 위치하는 superior type의 경우 전체 220예 중 52예 (24\%)에서 관찰되었으며, inferior type은 168예(76\%)에서 관찰 되었다. 평균 계측치의 변화는 superior type인 경우 inferior type과 비교하여 Line 1, Line 3의 평균 계측치가 짧아지고 Line 2 의 평균 계측치는 길어지는 것으로 조사되었으며, 이는 접형동의 자연공과 터키안과의 위치 관계가 터키안의 높이의 변화가 아닌 접형동 자연공의 위치에 따라 결정되는 것으로 판 단된다. 이런 이유로 접형동 전벽을 제거하여 확장하는 경우 superior type은 접형동 전벽을 하측으로 충분히 확장하여 수술 시야를 확보하는 것이 필요하다 생각된다. 그리고 superior type 에서 Line 3 의 평균 계측치가 짧아지는데, 이는 접형동 자연공 에서 터키안까지의 거리가 짧음을 의미하며, 수술 중 자연공을 통한 기구 삽입시에 터키안 전벽의 손상 위험성이 높기 때문 에 세심한 주의가 필요하다 판단된다.

\section{REFERENCES}

1) Fujii K, Chambers SM, Rhoton AL Jr. Neurovascular relationships of the sphenoid sinus. A microsurgical study. J Neurosurg 1979;50(1): 31-9.

2) Tan HK, Ong YK. Sphenoid sinus: an anatomic and endoscopic study in Asian cadavers. Clin Anat 2007;20(7):745-50.

3) Kim HU, Kim SS, Kim IS, Chung IH, Yoon JH. Morphology of middle septum and accessory septum of the sphenoid sinus. Korean J Otolaryngol-Head Neck Surg 2001;44(2):153-6.

4) Kim HU, Kang JW, Chung IH, Yoon JH, Lee JG. Pneumatization of the sphenoid sinus and its surrounding neurovascular structures. Korean J Otolaryngol-Head Neck Surg 2001;44(3):272-7.

5) Cho JH, Kim JK, Lee JG, Yoon JH. Sphenoid sinus pneumatization and its relation to bulging of surrounding neurovascular structures. Ann Otol Rhinol Laryngol 2010;119(9):646-50.

6) Albrecht K, Nave H, Breitmeier D, Panning B, Tröger HD. Applied anatomy of the superior vena cava-the carina as a landmark to guide central venous catheter placement. Br J Anaesth 2004;92(1):75-7.

7) Lee SK, Park YS, Cho JH, Park YJ, Kang JM, Jeon EJ, et al. Anatomic variations of sphenoid sinus and related neurovascular structures: a study of CT analysis. Korean J Otolaryngol-Head Neck Surg 2004;47(10):978-82.

8) Enatsu K, Takasaki K, Kase K, Jinnouchi S, Kumagami H, Nakamura $\mathrm{T}$, et al. Surgical anatomy of the sphenoid sinus on the CT using multiplanar reconstruction technique. Otolaryngol Head Neck Surg 2008; 138(2):182-6.

9) Wu HB, Zhu L, Yuan HS, Hou C. Surgical measurement to sphenoid sinus for the Chinese in Asia based on CT using sagittal reconstruction images. Eur Arch Otorhinolaryngol 2011;268(2):241-6.

10) Chung SW, Mo JH, Chung YJ. Feasibility and safety of superolateral sphenoidotomy: radiologic study by analyzing multiplanar reconstructive CT scans. Korean J Otorhinolaryngol-Head Neck Surg 2011; 54(6):399-402.

11) Hammer G, Radberg C. The sphenoidal sinus. An anatomical and roentgenologic study with reference to transsphenoid hypophysectomy. Acta radiol 1961;56:401-22.

12) Turgut S, Gumusalan Y, Arifoglu Y, Sinav A. Endoscopic anatomic 
distances on the lateral nasal wall. J Otolaryngol 1996;25(6):371-4.

13) Cavallo LM, Messina A, Cappabianca P, Esposito F, de Divitiis E, Gardner P, et al. Endoscopic endonasal surgery of the midline skull base: anatomical study and clinical considerations. Neurosurg Focus 2005;19(1):E2.

14) Anon JB, Lipman SP, Oppenheim D, Halt RA. Computer-assisted endoscopic sinus surgery. Laryngoscope 1994;104(7):901-5.

15) Hosemann W, Gross R, Göde U, Kühnel TH, Röckelein G. The anterior sphenoid wall: relative anatomy for sphenoidotomy. Am J Rhinology 1995;9(3):137-44.

16) Min YG, Shin JS, Lee CH. Trans-superior meatal approach to the sphenoid sinus. ORL J Otorhinolaryngol Relat Spec 1995;57(5):28992.

17) Metson R, Gliklich RE. Endoscopic treatment of sphenoid sinusitis. Otolaryngol Head Neck Surg 1996;114(6):736-44.

18) Orlandi RR, Lanza DC, Bolger WE, Clerico DM, Kennedy DW. The forgotten turbinate: the role of the superior turbinate in endoscopic sinus surgery. Am J Rhinol 1999;13(4):251-9.
19) Hayakawa K, Yoshikawa H, Suzuki M, Yokoi H, Hosokawa A, Hagiwara A, et al. Variations in reciprocal distances between the ethmoidal sinus, sphenoidal sinus and posterior orbit: measurement on CTscans. Juntendo Med J 2003;49(1):89-96.

20) Elwany S, Yacout YM, Talaat M, El-Nahass M, Gunied A, Talaat M. Surgical anatomy of the sphenoid sinus. J Laryngol Otol 1983;97(6): 227-41.

21) Fujii M, Goto N, Shimada K, Moriyama H, Kikuchi K, Kida A. Demonstration of the nasal septal branches of the sphenopalatine artery by use of a new intravascular injection method. Ann Otol Rhinol Laryngol 1996;105(4):309-11.

22) Van Alyea OE. Sphenoid sinus: anatomic study, with consideration of the clinical significance of the structural characteristics of the sphenoid sinus. Arch Otolaryngol 1941;34(2):225-53.

23) Lang J. Clinical anatomy of the nose, nasal cavity and paranasal sinuses. New York, USA: Thieme Medical Publishers;1989. p.129-30.

24) Yeoh KH, Tan KK. The optic nerve in the posterior ethmoid in Asians. Acta Otolaryngol 1994;114(3):329-36. 